Storey Institute. An interesting series of lectures has been arranged, not restricted to chemistry, but likely to attract scientific workers and all interested in the progress of science.

\section{Civil Engineering in Local Government}

Sir Henry Maybury delivered his presidential address to the Institution of Civil Engineers on November 7, dealing with aspects of engineering associated with local and central government administration in Great Britain. Up to about forty years ago, county and local engineers and surveyors were often part-time officers only. The Locomotives on Highways Act, 1896, by permitting a speed of 12 miles an hour upon the highways, gave great impetus to the construction of the motor-car ; this type of traffic imposed a strain upon the roads, which had never been designed or constructed for it, and indeed had received little or no attention since the commencement of the railway era. The Motor Car Act, 1903, allowed increased speed and greater freedom to the motor vehicle, but gave no relief to highway authorities and their officers. Under the Development and Road Improvement Funds Act, 1909, the Road Board was established primarily to receive the moneys derived from this taxation, and to allocate them to local authorities for road improvement works. In 1919 the Ministry of Transport was established, with control of all forms of transport, and in 1920 the passing of the Roads Act made it possible for contributions from the Exchequer to be made to local authorities towards the cost of the maintenance and minor improvement of classified roads, further sums being made available for necessary road and bridge construction and for major improvements. Speaking of the development of the love of travel in post-War years, Sir Henry said that whilst each person in Greater London travelled on an average 283 times on one or other of the rail and road services in 1912, in 1932 the number of journeys per person had risen to 482 . In conclusion, Sir Henry said that there are on the roll of the Institution of Civil Engineers nearly 11,000 members resident in all parts of the world, and he appealed particularly to the younger members to fit themselves adequately for the responsibilities of their profession.

\section{A Three Million Volt Testing Laboratory}

The Compagnie Générale d'Electro-Ceramique manufactures high-voltage insulators at Ivry, near Paris. In 1923, it erected the first million volt testing laboratory in Europe. It has now installed new plant which enables it to produce electric discharges up to three million volts, the rate of pressure rise being adjustable to any required speed. The discharges are recorded by a 50,000 volt cathode ray oscillograph. The building, which has no windows through its walls, measures $118 \mathrm{ft}$. in length, $65 \mathrm{ft}$. in width and $59 \mathrm{ft}$. in height. In the Electrical Review of October 27, there is a picture giving a general view of the inside of the laboratory. The roof is carefully connected to earth in such a way that the building forms a Faraday cage. The transformers giving a million volts have been improved. The discharging spheres are $39 \mathrm{in}$. in diameter. The new artificial lightning producer is built up of one hundred 0.5 microfarad, 30,000 volt condensers mounted in the form of a tower, one above the other. The earthing circuit of the condenser is completely independent of that of the building. The earthing plates are sunk in the underground water of the Seine and are connected with the condensers by means of two pits. With all the condensers coupled in series, a maximum of 3,000 amperes at three million volts can be obtained. The total energy of the discharge is 22,500 joules and the maximum instantaneous power developed is about nine million kilowatts. To measure the potential of the arc, two brass balls each having a diameter of 6.5 feet and weighing about $10 \mathrm{cwt}$. are employed. At three million volts the length of the spark exceeds thirteen feet.

\section{Electrically Propelled Tugs}

THe two tugs, the Acklam Cross and the Lectro, recently put into service, are interesting owing to the fact that they are both electrically propelled and, furthermore, the first two tugs in Great Britain utilising the electric drive. As the Acklam Cross also has a battery for starting the main Diesel engines, for which purpose the generators are used as motors, it has another claim to distinction, for this is the first occasion that such an arrangement has been used aboard ship. These two tugs will be used on different services, as the Acklam Cross, owned by the Tees Towing Co., Ltd., will be on general towage work, whilst the Lectro, owned by the Union Lighterage Co., Ltd., will operate on the Thames, towing oil barges between shell Haven and Fulham. Although the above-mentioned craft are the first of their type in Great Britain, there are more than fifty electric tug boats in the United States, as well as a number in Europe, and the total number of electrically driven ships in the world is considerably more than two hundred. Out of this number, there are now three, including the new tugs, operating entirely in British waters, the other one being the R.M.S. Lochfyne, a small passenger ship completed in 1931. All these vessels have Diesel electric propelling machinery. It is significant that even in the present time of economic depression, machinery has been adopted higher in first cost than the steam engine or direct Diesel drive, and it remains to be seen if the advantages claimed for the electrically driven tug will be proved, and result in its adoption in the future on a much wider scale than at present in the British Isles.

\section{Awards of the Institution of Civil Engineers}

THE following awards of the Institution of Civil Engineers have recently been made for papers read during the session 1932-33. For papers read and discussed at ordinary meetings : A Telford gold medal and the Indian premium to Mr. Robert Mair (Calcutta) ; a George Stephenson gold medal and a Webb prize to Mr. H. W. H. Richards (London); a Telford premium jointly 